\title{
Organizační učení v odborných diskurzech ${ }^{\mathbf{1}}$
}

\author{
Bohumíra Lazarová, Milan Pol, Lenka Hloušková, Petr Novotný, \\ Martin Sedláček
}

Masarykova univerzita, Filozofická fakulta, Ústav pedagogických věd

Redakci zasláno 19. 1. 2012 / Do tisku přijato 19.4. 2012

\begin{abstract}
Abstrakt: Autoři textu pojednávají o pojmu organizační učení. Poukazují na širokou škálu jeho definic a pojetí, upozorňují na některé odlišnosti od pojmů př́ibuzných či analogicky používaných, jako je např. znalostní management či učící se organizace. Všímají si pak zejména vybraných diskuzí, které se $\mathrm{k}$ tomuto tématu vztahují. Jde o úrovně, na kterých může organizační učení probíhat, a vliv organizačního učení na chování, resp. výkon organizace. V další části textu je organizační učení představováno jako proces a jsou zde popsány fáze organizačního učení tak, jak se uvádějí v literatuře tomuto tématu věnované. Účelem textu je podat přehled snah o vymezení organizačního učení včetně kritických diskuzí. Poslední část textu je pak věnována vybraným teoriím a empirickým zkušenostem s organizačním učením ve školním prostředí. Autoři zdůrazňují význam organizačního učení pro školy jako specifické organizace a zároveň požadavek výzkumu procesů organizačního učení v tomto pracovním kontextu.
\end{abstract}

Klíčová slova: organizační učení, učící se organizace, organizační rozvoj, škola jako organizace, učící se škola, organizační učení ve škole

\section{1 Úvod}

Téma organizačního učení nabývá na významu a oblibě zejména ve spojitosti s proměnou požadavků na chování organizací. Od těch se ve stále větší míře očekává a často i vyžaduje schopnost učit se z vlastní i zprostředkované zkušenosti v zájmu rozvoje z vnitřních zdrojů a v zájmu posílení schopnosti přizpůsobovat se, měnit se v proměňujících se společenských podmínkách. Týká se to organizací prakticky v každé oblasti lidské činnosti, tedy například i ve vzdělávání a výchově, ve sféře veřejné, soukromé, státní či jiné. Téma organizačního učení je tématem interdisciplinárním, je svázané s celou řadou vědních disciplín (kulturní antropologie, psychologie, pedagogika, management aj.) a dílčích teorií (teorie učení, teorie organizačního rozvoje,

1 Text vznikl za podpory grantového projetu č. P407/10/1197 s názvem Procesy organizačního učení ve škole a jejich vedení a řízení financovaného Grantovou agenturou České republiky. 
organizační procesy a strategie, kolektivní poznání apod.). Výzkumně se sleduje $\mathrm{v}$ různých pracovních kontextech a organizacích, které se liší svým posláním, cílem, strukturou i dalšími charakteristikami.

Počátky používání pojmu organizační učení se vztahují ke konci padesátých let minulého století a od té doby lze zaznamenat postupný nárůst snah vysvětlit a popsat organizační učení z hlediska různých vědních disciplín a dílčích teorií (Sun \& Scott, 2003). Zejména v osmdesátých a devadesátých letech vznikla řada teoretických pojednání zaměřených na organizační učení. V téže době sílí poptávka po empirických výzkumech věnovaných tomuto tématu, ale vývoj v tomto směru šel pomaleji. Zatímco na prahu devadesátých let byly výzkumné texty zaměřené na organizační učení spíše ojedinělé, dnes je nabídka takto založených publikací velmi široká (srov. Argyris, 1992; Crossan et al., 1995, 1999; Dodgson, 1993; Easterby-Smith, 1997; Fiol \& Lyles, 1985; Huber, 1991; Levitt \& March, 1988; Miller, 1996; Sun \& Scott, 2003 aj.).

S mírným zpožděním, $\mathrm{v}$ devadesátých letech minulého století, se v zahraničí objevily texty zaměřené na problematiku organizačního učení ve školách (Leithwood, Jantzi, \& Steinbach, 1998; Senge et al., 2000; Louis, 2006; Verbiest, 2002 aj.). Jejich autoři se snažili sledovat procesy organizačního učení ve školním prostředí s oporou o práce zaměřené na jiné organizace. U nás prozatím chybí empirické studie, které by uceleněji sledovaly procesy organizačního učení ve školách, a event. na tomto základě jasněji a na konkrétních př́kladech naznačovaly možné cesty k jeho rozvoji a podpoře.

I přes tuto bohatou zdrojovou základnu a širokou diskuzi není organizační učení uchráněno mnoha dezinterpretací. Organizační učení je nezřídka zaměňováno za rozvinutý systém podnikového vzdělávání, případně je využíváno jako koncept legitimizující mocenské (manažerialistické) zásahy do chodu organizací (Harrison, 2000; Novotný, 2009). Proto je nutné prohlubovat teoretickou analýzu a kritický výklad organizačního učení, o což usiluje i tento text. Účelem tohoto textu je podat přehled snah o vymezení organizačního učení včetně související kritiky. Představujeme organizační učení jako složitý a mnohovrstevnatý proces a uvažujeme o něm jako o tématu pro školní prostředí. 


\section{Organizační učení - stávající definice a pojetí}

Diskuzi o organizačním učení dnes představuje extrémně rozsáhlá informační základna akademických i neakademických (především manažersky orientovaných) textů. Problém, o kterém tento koncept hovoří, evokuje řadu pojetí, která se odrážejí v množství různých definic. Půdorys pro toto uvažování vymezují tři témata a jejich vzájemné vazby: znalost, chování a vnější vztahy organizace. Jakkoliv jde při definování organizačního učení v principu vždy o dynamiku tvorby a využívání znalostí pro změnu chování organizace ve prospěch vyhovění úkolu organizace vymezenému vnitřním i vnějším prostředím, jsou akcenty různých vymezení dosti variabilní.

Vztahy mezi organizačním chováním a prostředím (např. Daft \& Weick, 1984) jsou nezbytným výchozím bodem, od kterého se odvíjí další vymezování organizačního učení. $\mathrm{V}$ tomto směru neformulují autoři vymezující organizační učení zásadně nové teze, v podstatě pokračují v linii uvažování o organizacích jako otevřených entitách $\mathrm{v}$ bohatých vnějších vztazích (srov. Pol et al., 2005; Novotný, 2009), jejichž význam podtrhují odkazem na turbulentní vnější prostředí (Senge, 2007; Huber, 1991).

$\mathrm{K}$ tvorbě a využívání znalostí v kontextu organizačního učení se autoři vyjadřují dvojím způsobem s oporou o dvojí východiska. Jedni akcentují tok informací v organizaci, rozvoj znalostí či budování organizační paměti (např. Huber, 1991; Kim, 1998), čímž organizační učení přibližují k managementu znalostí. Druzí sledují především kognitivní procesy v psychosociálním smyslu: změny v poznání, tvorbu a sdílení významů, prohlubování porozumění (např. Cavaleri \& Fearon, 2000; Fiol \& Lyles, 1985). Pokusy definovat organizační učení na základě znalostí a jejich toku, tvorbě a sdílení, jsou předmětem dílčí kritiky dalších autorů. Tak například Bontis, Crossan a Hulland (2002) zdůrazňují nutnost rozlišovat mezi organizačním učením, managementem znalostí a intelektuálním kapitálem. Zatímco intelektuální kapitál vnímají jako určitou zásobu znalostí (stock of knowledge) přítomnou $\mathrm{v}$ určitém čase, tedy to, co je naučeno v kognitivním slova smyslu, doménou znalostního managementu je tok (flow) znalostí v průběhu času. Organizační učení pak rozšiřuje pozornost o prvek chování a nabízí vysvětlení, jak se znalosti v organizaci na různých úrovních proměňují a jak plynou v čase. Tím se otevírá prostor pro definice organizačního učení, které kladou do ohniska svého zájmu změnu chování. 
Definice akcentující změnu chování integrují vliv poznání na změnu chování lidí a organizací do uvažování o podpoře výkonu organizace (např. Crossan et al., 1995) a otevírají tím otázku, k čemu má organizační učení vést. V užších vymezeních vede organizační učení k odhalování a korekci chyb, zvládání problémů v činnosti či rozhodování (např. Argyris \& Schön, 1978; Levitt \& March, 1988; Miller, 1996).V širších vymezeních má mít organizační učení význam v odhalování rutin a stereotypů (např. Crossan et al., 1995) bránících organizaci v dosahování výkonu, případně je organizační učení komplexní cestou k inovacím, ke zvyšování efektivity a produktivity, ke strategické obnově (Crossan et al., 1999; Stata, 1989).

Představa o neoddělitelnosti organizačního učení a viditelného zvyšování výkonu organizace (případně inovativního chování) vychází z předpokladu, že existuje stav nula, tj. stav, kdy učení neprobíhá, učení je tedy a priori pozitivním procesem. Požadavek viditelného zlepšování výkonu organizace v důsledku organizačního učení není přijímaný jednoznačně, nebot', podle některých (srov. Bapuji \& Crossan, 2004; Koenig, 2006), lze do organizačního učení zahrnout přirozené, kontinuální a všudypřítomné učení, jehož stimulem je jednoduchá a nereflektovaná změna chování v reakci na změněnou situaci, resp. problém (tzv. učení $\mathrm{v}$ jedné smyčce) ${ }^{2}$. Na druhé straně může toto „Všudypřítomné“ organizační učení vést pouze k zachování statu quo či ke změnám, jejichž užitek nelze bezprostředně prokázat (Argyris, 1992).

V diskuzích o organizačním učení se také objevuje otázka, zda je organizační učeníkonceptem deskriptivním(resp.interpretativním), nebo preskriptivním. Sun a Scott (2003) v tomto kontextu věnují pozornost rozdílům mezi organizačním učením a učící se organizací. Podle nich je podmínkou učící se organizace změna v chování, která posunuje organizaci kpožadovanému stavu, kdežto v organizačním učení se zdůrazňuje spíše samotný proces učení, tedy to, jak se lidé a organizace učí. V tomto duchu má koncept organizačního učení deskriptivní charakter a zabývá se procesy učení, které se vyskytují v každé organizaci přirozeně (představa o „Všudypřítomném“ organizačním učení však není všeobecně přijímána). Na druhé straně pojem učící se organizace zahrnuje „předepsanou nutnost“ (má preskriptivní charakter) vytvořit určitý

\footnotetext{
Učení v jedné smyčce (single loop learning) je učení, které spočívá „pouze“ v řešení aktuálního problému, aniž by docházelo k reflexi cílů, hodnot, teorie apod. (srov. Argyris, 1992; Pol, 2007). Tento typ učení Argyris (1992) přirovnává k reakci termostatu na změnu teploty v místnosti, jehož cílem je udržet nastavenou teplotu. Dvousmyčkové učení (double loop learning) by pak směřovalo ke snahám odhalit příčiny kolísání teploty v místnosti.
} 
„ideální“ typ či formu organizace; učící se organizace musí vynaložit úsilí pro implementaci změn, aby nastal rozvoj. Lze tak říci, že sledování organizačního učení je spíše akademickou doménou, kdežto dosahování učící se organizace (resp. přibližování se k tomuto ideálu) je veskrze praktickou záležitostí. Řada autorů má za to, že pozorovatelná tendence nerozlišovat striktně mezi pojmy organizační učení a učící se organizace plyne také z přesvědčení, že snahy o dosažení charakteristik učící se organizace jdou skrze rozvoj organizačního učení, které pak již není jen přirozeným a všudypřítomným procesem, ale zahrnuje reflektované zpracovávání zkušenosti i práci s hodnotami (srov. Sun \& Scott, 2003).

Pro účely vymezování organizačního učení je také nutné vyjasnit, na jakých úrovních organizační učení probíhá. Tato otázka má dvě roviny: jaké jsou úrovně organizačního učení a jaké jsou vazby těchto úrovní. První rovinu představuje problém, na jaké úrovni uskupení lidí (aggregation) má smysl hovořit o organizačním učení. Organizační učení se považuje za víceúrovňové a bývá popisované na úrovni individuální (nebo také inter-individuální), skupinové (nebo také inter-skupinové) a organizační (Argyris, 1992; Bapuji \& Crossan, 2004; Verbiest, 2002), což vytváří zdánlivý paradox (úroveň organizační jako jedna z úrovní organizačního učení). Tento paradox je reflexí provázanosti všech tří úrovní organizačního učení. Bylo opakovaně prokázáno (typicky Argyris \& Schön, 1996), že procesy individuálního učení $\mathrm{u}$ jedinců v organizaci a organizační rozvoj jsou vzájemně silně podmíněné a nevyváženost obou těchto procesů limituje schopnost organizace překonávat bariéry rozvoje a adaptovat se na změny vnějšího prostředí (Harrison, 2000). Také lze mít za prokázané, že jsou to skupiny lidí uvnitř organizace, v jejichž rámci se tvoří a sdílí znalost zásadní pro schopnost organizace se rozvíjet (Harrison, 2000). Hoeve a Nieuwenhuis (2008) zdůrazňují, že pro proces učení je zásadní interakce mezi učící se entitou a jejím okolím a tato interakce je významnější než každý jednotlivý prvek sám o sobě. Individuální učení směřuje ke zvládání individuálního úkolu a je určováno především interakcí mezi jedincem a dalšími členy pracoviště, je ale také spoluurčováno procesy probíhajícími v organizaci a vnějším sociálním i ekonomickým kontextem. Kolektivní učení na úrovni skupiny pracovníků probíhá především v interakci skupiny s organizací, nicméně zde opět zprostředkovaně vystupuje také učení individuální a v opačném směru v hierarchii také sociální a ekonomický kontext. A konečně klíčem k porozumění organizačnímu učení je interakce organizace a vnějšího prostředí. 0 organizačním učení tedy má 
smysl hovořit na každé úrovni, u všech procesů učení, které určují změnu interakce organizace s vnějším prostředím.

V tomto kontextu se ukázalo jako př́nosné oddělovat v uvažování o organizačním učení procesy učení jako takové od kapacity k učení, tzn. od připravenosti mechanismů učení a jeho podpory v organizaci na všech relevantních úrovních (Marsick, 1994). Konkrétně jde o rozvinutost mechanismů tvorby a sdílení znalostí, o kulturu a klima příznivé pro sdílení a konečně o mechanismy „koordinované systémové změny“ v organizaci (Marsick, 1994).

Terminologická nejednotnost a prolínání různých pojetí a tedy i definic organizačního učení vyžaduje vyjasnění pozic některých zjednodušujících přístupů a předcházení záměně s př́buznými koncepty, které jsou s organizačním učením spojovány a ne vždy jsou jasně odlišeny. Sami autoři tohoto textu se přiklánějí k pojetí, které reprezentují Bapuji a Crossan (2004), když navrhují pojímat a zkoumat organizační učení v celé jeho možné šíri podob. Organizační učení tedy lze podle nich chápat jako exogenní i endogenní (záleží na úrovni zapojení lidí a kontextu), vyvolává změny kognitivního i behaviorálního charakteru, které může být metodicky vedené (k tomu níže), může se rozvíjet postupně i velmi rychle (srov. také Koenig, 2006) a má zásadní vliv na výkon organizace.

\section{Organizační učení - kritická diskuze}

Je zřejmé, že takto široká škála pohledů i nejednotnost ve vymezování vzbuzují bohatou kritickou diskuzi. Objevilo se několik kategorií námitek zpochybňujících koncept organizačního učení jako takový, případně přínosy organizačního učení. Tyto námitky lze prezentovat v několika otázkách: Může se organizace učit? Vedou procesy učení nutně k pozitivním výsledkům? Je učení realizovatelné v rozporném a konfliktním prostředí organizací? Je organizační učení možno řídit a vést?

První pochybnost a zároveň téma $\mathrm{k}$ diskuzi v sobě nese propojení pojmů učení a organizace. Představa organizace coby učící se entity je premisou uvažování o organizačním učení. Přesto je idea učení na úrovni nadindividuálních sociálních jednotek svým způsobem problematická (Cook \& Yanow, 1996), což má původ mnohem hlouběji v sociálně-vědním uvažování a jeho vnitřních rozporech. Existují dva náhledy na nadindividuální sociální jednotky (tedy i organizace), tedy nejen na otázku učení (Mullen \& Goethals, 1987). 
Jeden proud uvažování staví na myšlence, že jsou svébytnou entitou. Druhý proud uvažování se zase opírá o tezi, že sociální jevy jsou vždy dány individuálním jednáním, a lze jim porozumět pouze skrze interpretaci individuálního jednání. Stejně jako v diskuzi o podstatě skupinových jevů (Mullen \& Goethals, 1987) je v diskuzi o organizačním učení nejběžnějším principem integrace obou perspektiv paralelismus mezi skupinou a individuem (Bratton et al., 2004).

První zmínky o kolektivním poznání a učících se organizacích tedy vyvolaly mj. námitky o nevhodném antropomorfismu. Organizace přece nemyslí a je logické, že učení v organizacích jde pouze skrze jedince (např. Dodgson, 1993). Tento pohled však byl záhy marginalizován a brzy byla šířeji přijata definice učení, resp. poznání ve vztahu k rozvoji organizace jako př́jem informací, hromadění, zpracovávání a využívání ve prospěch změny v chování lidí i organizace jako celku. Výskyt učení byl rozlišen a popsán na různých sociálních úrovních, tedy i na organizační (Bapuji \& Crossan, 2004; Koenig, 2006). Pro účel uvažování o organizačním učení je třeba akceptovat (s výhradou danou výše uvedenými pochybnostmi), že učení na úrovni organizace není pouhou metaforou, ale skutečným fenoménem vedoucím ke kolektivnímu zvládání pracovních úkolů. Organizace jsou tedy považovány za klíčová místa pro učení a má se za to, že jsou také zároveň samy schopny procházet procesem učení.

Přijímáme-li tedy organizační učení za prokázaný fenomén, je třeba přezkoumat jeho faktický př́nos pro organizaci. Argyris (1992) v této souvislosti zdůrazňuje etický rámec organizačního učení (organizace se mohou učit i „,špatné věci“) a přiklání se k požadavku tzv. produktivního učení (productive learning), jehož výsledkem je popsatelná pozitivní změna. Levitt a March (1988) však upozorňují, že organizační učení nemusí nutně vést k „inteligentnímu chování“. Tytéž procesy, které vedou k pozitivním změnám chování organizace v souladu s vnějšími i vnitřními požadavky, mohou vést také k chybným závěrům a dokonce ke lpění na chybných závěrech. Příčiny selhávání jsou však slabě empiricky doloženy a koherentní výčet faktorů ohrožujících organizační učení chybí (Lu, Leung, \& Koch, 2004). Problémy bývají připisovány překážkám, které pro učení vznikají na mnoha úrovních. Mohou pramenit z nedostatků lidských kognitivních návyků, částečně z rysů organizace a z charakteristik struktury nutně limitované zkušenosti (Levitt \& March, 1988; Castleton, Gerber, \& Pillay, 2004). 
Literatura také dokumentuje mnoho případů selhávání v podpoře sdílení znalostí v organizaci, protože lidé a skupiny odmítají své znalosti sdílet s druhými. Toto selhávání je interpretováno jako důsledek rozmanitých faktorů, mimo jiné vlivu organizační kultury, uplatňování osobních a mocenských zájmů atd. (Lu et al., 2004). Také změna rutin, nutně spojená s učením, může být u různých skupin pracovníků přijímána nejednotně a u některých vyvolávat spíše rezistenci vázanou na problémy v motivaci $\mathrm{k}$ učení, ale i v pracovním výkonu, na konflikty mezi zaměstnanci a řídícími pracovníky i mezi zaměstnanci navzájem apod. (Elkjaer, 2009; Employee..., 2008). Dalším problémem je limitovaná zkušenost jedince, skupin i organizace jako celku, což kontrastuje $\mathrm{s}$ - v principu - neomezenými požadavky na zvládání pracovních rolí a organizačních úkolů. Přímá zkušenost je na jedné straně nejefektivnějším zdrojem učení, na druhé straně mnohá důležitá rozhodnutí se ukážou být (ne)efektivní, (ne)smysluplná a (ne)racionální teprve s významným časovým odstupem. „Nejkritičtější rozhodnutí, která se v organizacích přijímají, mají celosystémové důsledky, jejichž působení se rozprostírá na celé roky a na celá desetiletí" (Senge, 2007, s. 41), a proto je obtížné se na jejich základě učit.

Pochybnosti provází i diskuze o možnosti řídit a vést procesy organizačního učení. Je-li organizační učení víceúrovňové (jak bylo představeno výše), pak nelze opominout, že učení v individuální, skupinové a organizační úrovni potenciálně probíhají v různém rytmu a v různých cyklech. Situace, kdy se rozchází rytmus či směr individuálního, skupinového a organizačního učení, je z pohledu řízení učebního procesu problematická (Cutcher-Gershenfeld \& Ford, 2005; Elkjaer, 2009). V manažerialistických řešeních pro takovouto situaci není místo, jako ideál jsou prezentovány iniciativy organizačního učení, programy změny nebo systémy řízení znalostí nebo výcviku postavené na slad'ování učebních cyklů, na silných vizích zaměřených na produkci učení organizací a jejími zaměstnanci. Diskrepance učebních cyklů, rozpojení vizí a směru učení však realizaci vizí prokazatelně zpomalují a někdy zcela blokují (Cutcher-Gershenfeld \& Ford, 2005).

Přesto Cutcher-Gershenfeld a Ford (2005) dokládají, že rozpory v cyklech učení a organizačních změnách jsou zcela přirozené a mohou být dokonce produktivní. Namísto boje proti těmto rozporům jakožto ohrožení pro změnu, organizační učení, řízení znalostí či efektivitu výcviku obhajují rozpory jako jedinečné př́ležitosti pro nahlédnutí do fungování organizace, které jsou 
„zásadní pro úspěch mnoha iniciativ orientovaných na učení či znalosti“ (Cutcher-Gershenfeld \& Ford, 2005, s. 9) a předkládají mnohé návrhy určené praktikům $\mathrm{k}$ využití rozporů $\mathrm{v}$ učebních cyklech jako přednosti organizace. Evansová et al. (2006) dokonce dokladují situace, kdy osobní iniciativa zaměstnance může umožnit vytvoření mikrokultury učení v práci, a dokonce i bez aktivní podpory a zapojení zaměstnavatele.

Samozřejmě existují racionální strategie pro zmírnění některých z těchto problémů organizačního učení řízením a vedením, nicméně se ukazuje, že běžné organizační postupy ne vždy generují chování, které je v souladu s těmito strategiemi (Levitt \& March, 1988). Leithwood a Louisová (1998) $\mathrm{v}$ této věci upozorňují na meritorní problém $\mathrm{v}$ možnosti řízení procesů organizačního učení. Zatímco procesy vedení a řízení z principu směřují k uvádění organizací do „ekvilibria“, obnovují a udržují řád a konzistenci chování, procesy organizačního učení, organizační změny a rozvoje nutně generují "disekvilibrium", diskontinuitu, produkují nejistotu a chyby. Vyvažování těchto rozporů si bere za své tzv. transformační vedení (Leithwood \& Louis, 1998). Jiné možné řešení tohoto rozporu spočívá v tezi, že řídit nelze přímo procesy učení, nicméně řízení rozvoje kapacity pro učení je možné (Harrison, 2000).

Zde prezentovaná kritika konceptu organizačního učení jako takového, př́padně kritika směřovaná $\mathrm{k}$ jeho př́nosům a možnostem jeho vedení, zřejmě nemá sílu popřít existenci a význam procesů, které se pod označením organizační učení skrývají. Kritické argumenty však nabádají k opatrnější formulaci pozitivních očekávání spojených s organizačním učením.

\section{Organizační učení jako proces}

Snahy poznat organizační učení empiricky obvykle vycházejí z analýzy a popisu konkrétních psychosociálních procesů, které jsou základem učení. Jde zejména o to, jak nové informace a nová znalost mění chování organizace (tedy o vztah kognitivních a behaviorálních změn), a o to, jaká je cesta od učení se jedinců v organizaci k organizačnímu učení. Je zřejmé, že empiricky založené poznání těchto procesů není snadné, vyžaduje veskrze kvalitativní přístupy vázané ke konkrétnímu prostředí, organizaci i lidem, a výsledky takových snah jsou jen obtížně přenositelné a aplikovatelné v jiných organizacích. Na teoretické úrovni se pak ve snahách o vysvětlení procesů organizačního učení setkáváme mj. s aplikacemi celé řady zejména 
psychologických a sociálně psychologických teorií (kauzální teorie, teorie akce, teorie organizačního chování, teorie sebepojetí a jeho obran, teorie kognitivní disonance, teorie pole apod.).

Paralelně se snahami poznat a pochopit psychosociální procesy, které usnadňují či naopak komplikují organizační učení na individuální i skupinové úrovni, zdůrazňují mnozí autoři obecněji formulované, nejednotně terminologicky uchopované a více či méně vzájemně propojené a navazující fáze organizačního učení. Např. Huber (1991) popisuje učení v organizaci za využití konstruktů, které vycházejí spíše z teorie informace, a popisuje tak učení v linii: příjem informací, distribuce informací, interpretace informací a organizační pamět' (srov. také Sun \& Scott, 2003). Crossan et al. (1999) mají za to, že tři již zmíněné úrovně organizačního učení (individuální, skupinová a organizační) jsou propojeny čtyřmi širokými kategoriemi sociálních a psychologických procesů: uplatnění intuice (intuiting), intepretace, integrace a institucionalizace ${ }^{3}$. Prolínání těchto procesů, jejich přesnější popis a fungování na jednotlivých úrovních seskupení znázorňují autoři Crossan a Hulland v podobě tzv. rámce SLAM (Strategic Learning Assessment Map) (srov. Bontis et al., 2002).

Jedním z podstatných předpokladů organizačního učení je tedy příjem informací, resp. tvorba znalostí v organizaci, jejímž výsledkem je již zmíněný intelektuální kapitál (nebo také zásoba znalosti - stock of knowledge; Bontis et al., 2002). V souvislosti s vytvářením „zásob“ znalostí v organizaci se také používá pojem organizační pamět' (Huber, 1991; Sun \& Scott, 2003). Podle zdrojů informace/znalosti se pak organizační učení označuje jako (1) kongenitální (znalost, která v organizaci nebo mimo ni existuje již při jejím vzniku nebo také učení se z minulé zkušenosti jiných organizací; (2) zkušenostní (učení se $\mathrm{z}$ vlastní zkušenosti v organizaci); (3) zprostředkované nebo také interorganizační (učení se ze zkušeností jiných organizací); (4) převzaté (učení se od lidí, kteří nově vstupují do organizace, či učení vytvořené propojením organizací; srov. Bapuji \& Crossan, 2004).

V organizačním učení nejde jen o příjem informací, resp. navyšování znalostí $\mathrm{v}$ organizaci, ale především o porozumění tomu, jak jsou znalosti rozšiřovány, jak se rozvíjejí v prostoru a čase (Koenig, 2006). Huber (1991) v tomto kontextu hovoří o tzv. distribuci informací, která podle něj předpokládá procesy

Anglicky tzv. rámec čtyř „I“ (srov. Crossan et al., 1999), ve kterém je znázorněno, na jakých úrovních probíhají, resp. mohou probíhat zmíněné procesy. 
sdílení a rozvoj komunikačních cest. Mnohdy komplikovanou a netransparentní cestu od individuálního učení ke skupinovému a organizačnímu učení a chování označují Bontis et al. (2002) jako proces učení typu feed forward (explorace); učení typu feed back (exploatace) naopak vyjadřuje, jak učení a chování rozšiřrené v organizaci ovlivňuje individuální a skupinové učení. Za základ změny chování se pak považuje učení typu feed forward (explorace). Poznání a řízení napětí mezi explorací a exploatací považují tito autoři za jednu z kritických výzev pro studium organizačního učení (Bontis et al., 2002).

Důležitou součástí organizačního učení na individuální i skupinové úrovni je tedy vytvárení porozumění získaným znalostem. Na individuální (ale částečně i skupinové) úrovni sehrává významnou roli tzv. tacit knowledge (Sun \& Scott, 2003), tedy implicitní, nevyjádřená znalost, která se stává explicitní právě skrze sdílení. Na skupinové úrovni se vytváří společné porozumění skrze dialog a svou roli zde sehrává skupinová dynamika, která vede $\mathrm{k}$ rozvoji sdílených porozumění. Tato fáze zahrnuje interpretaci informací (Huber, 1991), tedy i práci s kognitivními mapami (někdy také kognitivními strukturami či mentálními modely apod.), které nejsou jen výsledkem individuální kognitivní struktury a individuální zkušenosti jedince, ale také kolektivní zkušenosti a sdílení (srov. také Senge, 2007).

Základem přechodu od individuálního učení k učení organizačnímu, který však zároveň evokuje nejvíce pochybností, pokud jde o možnosti zkoumání, je fáze integrace. Pojmem integrace bývá označováno sjednocení, ucelení či splynutí, spojování se ve vyšší celek (Kolektiv autorů, 1996). Tento proces probíhá na úrovni skupinové a organizační, předpokládá vzájemné přizpůsobení individuálního a skupinového, vyžaduje vytvoření systému interakcí, zahrnutí znalostí do organizačního systému (Bontis et al., 2002). Jde o integraci sdíleného porozumění do nových produktů, procesů, procedur, struktur a strategií, o to, jak jsou nové znalosti nebo úhly pohledu schopny ovlivňovat chování organizace (Mabey \& Salaman, 1995) a jak si organizace rozmanitým způsobem osvojují nejrůznější znalosti, metody a postupy (Argyris \& Schön, 1996).

\section{Organizační učení - téma pro školní prostředí}

V české odborné literatuře se lze setkat s publikacemi zaměřenými spíše na organizační učení v podnikové či firemní praxi, at' již jde o překlady (např. Senge, 2007) či původní díla (např. Novotný, 2009). Organizačnímu 
učení ve specifických kontextech (např. školách) se u nás věnuje pozornosti méně. Výzkumná pozornost je ve školském kontextu zaměřena spíše na fenomény, které s organizačním učením bezesporu souvisejí, jako např. kultuře školy, klimatu školy, spolupráci ve škole, formám kolegiální podpory apod. (srov. Eger \& Jakubíková, 1998; Grecmanová, 2008; Pol et al., 2005; Pol \& Lazarová, 1999 aj.). V zahraničí se organizačnímu učení ve školách (nebo školám jako učícím se organizacím či komunitám ${ }^{4}$ ) věnuje pozornost od 90. let minulého století (Leithwood \& Louis, 1998; Schratz \& Steiner-Löffler, 1998; Senge et al., 2000; Verbiest, 2002; Verbiest et al., 2005 aj.). Zde je třeba učinit upřesňující poznámku: jakkoliv by snad v ideálním případě organizační učení zahrnovalo i zainteresované laiky (rodiče a děti), většinově je pozornost věnována lidem profesně zainteresovaným ve škole, tzn. především učitelům a členům vedení školy (srov. Leithwood \& Louis, 1998; Verbiest, 2002).

Důvodů pro zkoumání a podporu organizačního učení ve školách je celá řada. Školy jsou považovány za specifické organizace nebo dokonce profesionální komunity, charakteristické nejen svým posláním, ale i prostorovým uspořádáním či strukturou pracovního času. Jsou v nich tedy i specifické podmínky pro rozvoj organizačního učení. Také školy čelí mnohým změnám, nejistotě a leckdy nejasným a proměňujícím se vnějším podmínkám. Existují v prostředí relativní decentralizace, autonomizace, a přitom se očekává, že budou skládat účty ze své práce. Řešením je tedy vnitřní rozvoj škol. Aby mohly školy zvládat požadavky kladené na ni rozmanitými subjekty vnějšího prostředí, čelit kontinuálním změnám (zavádění reforem do škol) a vyvíjet se směrem, který i lidé v ní budou považovat za smysluplný, musí být schopny vlastního učení (srov. Pol, 2007).

Podobně, jako se v obecných definicích organizačního učení rozlišuje úroveň individuální, skupinová a organizační, tak i Verbiest et al. (2005) identifikují u komunit profesního učení - škol tzv. personální kapacitu, interpersonální kapacitu a organizační kapacitu. Personální kapacita zahrnuje aktivní,

\footnotetext{
Ve školním kontextu se v souvislosti s organizačním učením stále častěji hovoří o tzv. komunitách profesního učení (professional learning communities). Komunita je sociální organizace spočívající ve vztazích spolupráce mezi lidmi, kteří sdílejí stejné cíle a kde denní život dospělých i žáků je organizovaný způsobem, který posiluje pozitivní vztahy mezi členy. Jádrem fungující (školní) komunity je permanentní osobní investice, důvěra, respekt a vzájemná závislost a zdůrazňuje se tlak na profesionalizaci učitelů (srov. např. Sergiovanni, 1994). Souvislost mezi organizačním učením, učící se organizací a učící se komunitou je zřejmá.
} 
reflektivní a kritickou (re)konstrukci znalosti. Interpersonální kapacita předpokládá sdílení hodnot, vizí a praxe a kolektivní učení. Organizační kapacita je vztahována k podpoře podmínek (struktury, kultury) a k vedení ze strany vedení školy. Uvedení autoři zároveň nabízejí představu o třech procesech, které probíhají v učících se komunitách. V procesu nazvaném rozšiřování (broadening) dochází $\mathrm{k}$ týmové práci napříč školou (od jedince k týmu), jde tedy o to, kdo se ve škole učí a v jak silné pospolitosti. V procesu zvaném prohlubování (deepening) lze empiricky popisovat obsahy předávaného, resp. hloubku spolupráce, která může začínat např. vtipkováním o žácích a přejít až ke skutečné spolupráci na kurikulu. Posledním procesem je pak tzv. kotvení (anchoring), ve kterém jde o míru podpory a vedení organizačního učení.

Popsat procesy organizačního učení a zejména probíhající psychosociální procesy včetně jejich vedení a řízení je možné pouze na konkrétních organizacích, nebot' jednotlivé fáze mají velmi individuální charakter a specificky je determinuje zejména kultura školy. Jakkoliv mohou snahy o zobecnění budit pochybnosti, někteří autoři se pokusili nabídnout dílčí výsledky výzkumů zaměřených na organizační učení ve školách. Obvykle však jde spíše o popis určitých izolovaných fenoménů spojených s učením se v organizaci, např. o výčet podpůrných faktorů a překážek organizačního učení. Tak například Leithwood et al. (1998) ve svém výzkumu identifikovali různé způsoby organizačního učení ve sledovaných školách a potvrdili dominantní výskyt informálního učení, tedy učení se od kolegů a z vlastní praxe, a také významné místo učení se prostřednictvím účasti na různých školeních. Louis a Kruse (1998) empiricky dokladují, že se ve školách oceňují spíše individuální znalosti, jako je orientace učitele $\mathrm{v}$ předmětu, dovednost zvládat žáky a trrídy apod. (tedy převaha procesů zaměřených na získávání poznatků nad jejich rozšiřováním). Ve školách se také, podle těchto autorů, nedostatečně využívá minulá zkušenost, problematické a obtížně sdělitelné je její propojení s orientací školy na její budoucí směřování. Empirická data z výzkumů realizovaných ve školách at' již kvalitativního nebo kvantitativního charakteru jsou často jen obtížně zobecnitelná, nicméně dávají možnost nahlédnout do nitra vybraných škol a porozumět procesům, které vedou k učení a ke změně v dané organizaci (srov. Leithwood et al., 1998; Goh, Cousins, \& Elliott, 2006; Verbiest et al., 2005). 


\section{Závěr}

V posledních desetiletích se zvýšil zájem o téma organizační učení zejména $\mathrm{v}$ souvislosti $\mathrm{s}$ organizačním rozvojem, a to $\mathrm{z}$ pochopitelných důvodů: organizace jsou komplexnější a jejich vývoj turbulentnější, je třeba učit se rychle a efektivně. Dynamika doby a procesů, které se v organizacích i mimo ně odehrávají, urychluje i procesy učení a stimuluje požadavky typu „učení se za chodu“, „analýza probíhajících akcí“ či „,kontinuální integrace“ (Koenig, 2006). Dnes se tedy považuje za potřebné, aby organizace ve vlastním zájmu poskytovaly nejen dostatek prostoru pro vzdělávání či proškolování lidí, které se odehrávají mimo organizaci, ale především, aby vytvářely podmínky pro mnohostranné učení probíhající přímo v organizaci (Pol, 2007). Klíčovým místem pro učení se stává vlastní pracoviště, učení je úzce spojeno s prací a organizační učení je prostředkem pro její zdokonalování (Novotný, 2009; Pol, 2007).

Snahy porozumět organizačnímu učení jako procesu lze sledovat v rovině teoretické i empirické. V rovině teoretické se setkáváme s celou řadou definic, kterése stávajívýchodiskem pro empirické výzkumyv mnohých organizačních kontextech. V důsledku takto široce vymezeného pojmu, je za organizační učení považována celá řada forem či podob učení od jednorázových školení až $\mathrm{k}$ diskuzím, reflexi nebo realizaci různých projektových aktivit. Za organizační učení může být považováno jak náhodné setkávání, ve kterém se hledá odpověd' na otázku či problém tak i systematické aktivity, v jejichž rámci je sběr a zpracování informací, hledání porozumění, interpretací či alternativních řešení. Výsledkem organizačního učení by však měla být změna chování na úrovni organizace, resp. tzv. produktivní chování organizace.

Školy lze považovat za specifické organizace, které vytvářejí specifický prostor pro organizační učení. $V$ porozumění organizačnímu učení ve školách je stále ještě mnoho viditelných mezer, což obzvláště platí v českém prostředí. Školy přitom čelí měnícím se, nejistým a rozporuplným podmínkám, zvládají zpracovávat rozmanité reformní a inovační požadavky, a to především silou svých vnitřních zdrojů. Právě proto se zkoumání organizačního učení ve školách stává zajímavou výzvou. 


\section{Literatura}

Argyris, Ch. (1992). On organizational learning. Malden/Oxford: Blackwell Publishing.

Argyris, Ch., \& Schön, D. (1978). Organizational learning: A theory of action perspective. Reading: Addison Wesley.

Argyris, Ch., \& Schön, D. (1996). Organizational Learning II. Reading: Addison-Wesley.

Bapuji, H., \& Crossan M. M. (2004). From questions to answers: reviewing organizational learning research. Management Learning, 35(4), 397-417.

Bontis, N., Crossan, M. M., \& Hulland, J. (2002). Managing an organizational learning system by aligning stocks and flows. Journal of Management Studies, 39(4), 438-465.

Bratton, J., Mills, J. H., Pyrch, T., \& Sawchuk, P. (2004). Workplace learning. A critical introduction. Aurora: Garamond Press.

Castleton, G., Gerber, R., \& Pillay, H. (Eds.). (2004). Improving workplace learning: Emerging international perspectives. New York: Nova Science.

Cavaleri, S. A., \& Fearon, D. S. (2000). Integrating organizational learning and business praxis: A case for intelligent project management. Learning Organization, 7(5), 251-258.

Cook, S. D. N., \& Yanow, D. (1996). Culture and organizational learning. In M. D. Cohen \& L. G. Sproull (Eds.), Organizational learning (s. 430-459). Thousand Oaks, CA: Sage Publications.

Crossan, M. M., Lane, H. W., White, R. E., \& Djurfeldt, L. (1995). Organizational learning: Dimensions for a theory. The International Journal of Organizational Analysis, 3(4), 337-360.

Crossan, M. M., Lane, H. W., \& White, R. E. (1999). An organizational learning framework: from intuition to institution. Academy of Management Review, 24(3), 522-537.

Cutcher-Gershenfeld, J., \& Ford, J. K. (2005). Valuable disconnects in organizational learning systems. New York: Oxford University Press.

Daft, R. L., \& Weick, K. E. (1984). Toward a model of organizations as interpretation systems. Academy of Management Review, 9(2), 284-295.

Dodgson, M. (1993). Organizational learning - a review of some literatures. Organization Studies, 14(3), 375-394.

Easterby-Smith, M. (1997). Disciplines of organizational learning: contributions and critiques. Human Relations, 50(9), 1085-1113.

Eger, L., \& Jakubíková, D. (1998). Podniková kultura a zlepšování kvality pracovního života ve školství (s. 170-183). In Efektivní školský management. Plzeň: Západočeská univerzita.

Elkjaer, B. (2009). Organizační učení a napětí coby jeho spouštěč v mnohohlasé aréně. In P. Novotný (Ed.), Pracoviště jako prostor k učení (s. 7-19). Brno: Masarykova univerzita.

Employee-driven innovation. Improving economic performance and job satisfaction. (2008). Kodaň: LO, Danish Confederation of Trade Unions.

Evans, K., Hodkinson, P., Rainbird, H., \& Unwin, L. (Eds.). (2006). Improving workplace learning. London: Routledge.

Fiol, M. C., \& Lyles, M. (1985). Organizational learning. Academy of Management Review, 10(4), 803-813.

Goh, S. C., Cousins, B., \& Elliott, C. (2006). Organizational learning capacity, evaluative inquiry and readiness for change in schools: Views and perceptions of educators. Journal of Educational Change, 7(3), 289-318. 
Grecmanová, H. (2008). Klima školy. Olomouc: Hanex.

Harrison, R. (2000). Learning, knowledge productivity and strategic progress. International Journal of Training and Development, 4(4), 244-258.

Hoeve, A., \& Nieuwenhuis, L. (2008). Researching routines; innovative lessons from a consultancy firm. In W. J. Nijhof \& L. Nieuwenhuis (Eds.), The learning potential of the workplace (s. 279-294). Netherlands: Sense Publishers.

Huber, G. P. (1991). Organizational learning: the contributing process and the literatures. Organization Science, 2(1), 88-115.

Kim, L. (1998). Crisis construction and organizational learning: Capability building in catchingup at Hunday Motor. Organization Science, 9(4), 506-521.

Koenig, G. (2006). L'apprentissage organisationnel: Repérage des lieux. Revue française de gestion, 160, 293-306.

Kolektiv autorů (1996). Slovník cizích slov. Praha: Encyklopedický dům.

Leithwood, K., Jantzi, D., \& Steinbach, R. (1998). Leadership and other conditions which foster organizational learning in schools. In K. Leithwood \& K. S. Louis (Eds.), Organizational learning in schools (s. 67-92). Lisse: Swets \& Zeitlinger.

Leithwood, K., \& Louis, K. S. (Eds.). (1998). Organizational learning in schools. Lisse: Swets \& Zeitlinger.

Levitt, B., \& March, J. (1988). Organizational learning. Annual Review of Sociology, 14, 319-340.

Louis, K. S., \& Kruse, S. D. (1998). Creating community in reform: Images of organizational learning in inner-city schools. In K. Leithwood \& K. S. Louis (Eds.), Organizational learning in schools (s. 17-46). Lisse: Swets \& Zeitlinger.

Louis, K. S. (2006). Changing the culture of schools: Professional community, organizational learning, and trust. Journal of School Leadership, 16(5), 447-489.

Lu, L., Leung, K., \& Koch, P. T. (2006). Managerial knowledge sharing: The role of individual, interpersonal, and organizational factors. Management and Organization Review, 2(1), $15-41$.

Mabey, C., \& Salaman, G. (1995). Strategic human resource management: A reader. Oxford: Blackwell.

Marsick, V. J. (1994). Trends in managerial reinvention: Creating a learning map. Management Learning, 25(1), 11-33.

Miller, D. (1996). A preliminary typology of organizational learning: Synthesizing the literature. Journal of Management, 22(3), 485-505.

Mullen, B., \& Goethals, G. R. (1987). Theories of group behavior. NY: Springer Verlag.

Novotný, P. (2009). Učení pro pracoviště. Brno: Masarykova univerzita.

Pol, M. (2007). Škola v proměnách. Brno: Masarykova univerzita.

Pol, M., Hloušková, L., Novotný, P., \& Zounek, J. (Eds.) (2005). Kultura školy. Př́spěvek k výzkumu a rozvoji. Brno: Masarykova univerzita.

Pol, M., \& Lazarová, B. (1999). Spolupráce učitelů - podmínka rozvoje školy. Praha: Strom.

Senge, P. M. (2007). Pátá disciplína: teorie a praxe učící se organizace. Praha: Management Press.

Senge, P. M., Cambron-McCabe, N., Lucas, T., Smith, B., Dutton, J., \& Kleiner, A. (2000). Schools that learn. A fifth discipline fieldbook for educators, parents, and everyone who cares about education. New York: Doubleday/Currency. 
Sergiovanni, T. J. (1994). Building community in schools. San Francisco: Jossey-Bass.

Schratz, M., \& Steiner-Löffler, U. (1998). Die lernende Schule. Innsbruck/Wien: Studien Verlag.

Stata, R. (1989). Organizational learning: The key to management innovation. Sloan Management Review, 30(3), 63-74.

Sun, P. Y. T., \& Scott, J. L. (2003). Exploring the divide - organizational learning and learning organization. The Learning Organization, 10(4), 202-215.

Verbiest, E. (2002). Collectief leren in scholen. Fontys: Tilburg.

Verbiest, E., Ansems, E., Bakx, A., Grootswagers, A., Heijmen-Versteegen, I., Jongen, T., Uphoff, T. W., \& Teurlings, C. (2005). Collective learning in schools described. Building collective learning capacity. Revista Electrónica Iberoamericana sobre Calidad, Eficacia y Cambio en Educación, 3(1), 17-38.

\section{Kontaktní údaje}

doc. PhDr. Bohumíra Lazarová, Ph.D., Masarykova Univerzita, Filozofická fakulta, Ústav pedagogických věd, Arna Nováka 1, 60200 Brno, e-mail: lazarova@phil.muni.cz

\section{Organisational learning in professional discourses}

Abstract: Authors of the paper discuss the concept of organisational learning. They refer to a wide range of definitions and concepts, point out some differences from related or analogous concepts used, such as knowledge management and learning organisation. They note the discussions that relate to key topics. These discussions concern levels at which organisational learning can take place, the effect on behaviour or organisational performance. The following section of this article presents organisational learning as a process and describes the stages of organisational learning. The purpose of the article is to provide an overview of efforts to define organisational learning, including criticism of the results of this effort. The last part is devoted to selected theories and empirical findings on organisational learning at school. The authors stress the importance of organisational learning for schools as specific organisations and express request to examine the processes of organisational learning in this context.

Keywords: organisational learning, learning organisation, organisational development, school as organisation, school as learning organisation 